\title{
Phenomenon of Mass Culture: Problems and Controversies
}

\section{Evgeniya Vladimirovna Kuznetsova}

The University of Management «TISBI»

kuznetzova.evgeniya2012@yandex.ru

\section{Olga Nikolaevna Goryacheva}

Kazan (Volga Region) Federal University olganikgor@mail.ru

\section{Gulchachak Rinatovna Patenko}

Kazan (Volga Region) Federal University werta71@mail.ru

\section{Doi:10.5901/mjss.2015.v6n4s2p296}

\begin{abstract}
The authors' subject of investigation is mass culture as a phenomenon. Material achievement is one of the reasons for the dominance of popular culture, because the quality of its products is measured by commercial interest. That's why the philosophy of mass culture is a philosophy of material success. The authors determine other characteristic features of mass culture and differentiate mass culture of industrial society and mass culture of postindustrial society. They highlight all dangers that exist in the development of mass culture and underline the importance of ethnic cultures' keeping. Modern popular culture in its global modern form is a system of values, lifestyle, style and way of thinking of the American cultural model. Each ethnonational identity has its own mentality, values, traditions, customs, in contrast to mass culture, elusive, and based on technological progress, and on the desire to please an audience. We should keep ethnic cultures. The authors note that the solution of this problem depends on the content of future generations, generations of civilization of the third wave.
\end{abstract}

Keywords: Mass culture, industrial society, mass media, clip-culture, communication.

\section{Introduction}

\subsection{Actuality of a Problem}

\subsubsection{Methods of Investigation}

The theory of education, with its cult of the equality of all religious traditions and the formation of the doctrine of rationalism formed the basis for the idea of a man being a self-sufficient creature. Medieval philosopher and catholic priest R. Guardini writes that a medieval individual «was absolutely less than God, but certainly more than any other creature, he was obedient to the will of the highest standing, and he directed all his energy to the spiritual domination about the world" [8, p.134]. The institutes of education and the era of modern times destroyed in his soul a sense of God. This era of modern times, namely the industrial civilization, formed a kind of mass consumer, owner of permissiveness. The technological revolution allowed mankind to make quite a few vital discoveries, but at the same time, advances in science and technology shaped the utilitarian idea of boundless faith in human thinking. Too much was connected with logic and rationality. We can say that one of the major mistakes of mankind is the predominance of the rational method of cognition as the only correct. This faith in mind led to another lurch of the industrial age. It is the loss of human being's moral and spiritual sense. One of the most serious defects of modern man's civilized consciousness is the sense of selfsuperiority over all alive and approval of the right of his domination on the Earth. So, R. Atfild sees the cause of many global problems in faith in progress. [1]. R. Atfild writes that according to Bible, "God cares for the welfare of all live, not just human, and people have to take care of nature, they have not to destroy their integrity under the own needs" [1, c.132]. 
But the man who had proclaimed himself Master on Earth, alone with himself remained weak and needing psychological protection. This function was performed by the religion. In the new age religious traditions had been destroyed, and function of protection had been transferred to mass culture that created and gave a man a new illusionary world.

In order to make conclusions concerning the phenomenon of mass culture we use a special historical method in our investigation as social and cultural processes of each social stage (industrial or postindustrial) determine the attributes of the phenomenon of mass culture. Also we use systematical method as it helps to produce the analysis of the problem from different points of view.

\section{The Historical Aspect}

For the first time in philosophical works and socio-psychological research in the end of the 19th century and the turn of the 19th and 20th centuries phenomena of mass culture, elite and elite culture have been digested. One of the first scientists, who had put the question of a completely new type of culture, was representative of the German philosophical school H.Herder. He differentiated the notions "culture" and "culture of the people." "Culture" is nothing more than a simple culture, not requiring any special conditions (education, training); A. Schopenhauer and Nietzsche sufficiently substantiate terms "mass" and "elite" culture.

A. Schopenhauer sees humanity consisting of "benefit" people who can only play, and "people-genius of artistic and creative activities" [18]. Nietzsche bases the idea of the "Super-human", an aristocrat with a spirit of creativity, aesthetic sensitivity [14]. The majority of mankind are defective men, slaves and instrumentalities, and it's possible to sacrifice their lives for the sake of the future. This is Nietzsche's thought in this context.

$\mathrm{N}$. Berdyaev also talks about the interplay of elite culture and mass culture, true culture and civilization. He believes that "only an elite needs a high culture, but masses of humanity need only secondary culture" [4]. According to his position the authentic culture can be created only by tribal elite, the aristocracy. Neither bourgeoisie, nor proletariat can do it.

These ideas are close to a famous Spanish philosopher Ortega-and-Gasset, the founder of phenomenon of mass culture and mass character. Popular culture, as he believes, is the mass culture of the perceptive person living in a box of delights, in the conviction that society and the state must satisfy his desires [15]. The man of the masses is the social type of personality and psychological phenomenon. He believes, that social origin does not determine the nature and level of education. He writes that you can meet exceptional characters in the work environment also. The mass man is limited, stereotyped, standardized. At the same time, he needs a world of fantasies and illusions, where he escapes from the complexities of the world. Freud, founder of psychoanalysis, also tries to address mass as a phenomenon in terms of emotional attachment, love. He proves that Eros and Thanatos are positive, erotic and aggressive [6]. The Eros is an instinct of species' conservation. Thanatos is the instinct of self-preservation, and if the first is always positive, the second can be a destructive beginning. Freud writes that the whole human history and sexual desire are closely related to each other. Accordingly, if we analyze the contents of products of modern mass culture, we can say that both of these instincts are reflected in those products.

Works by K. Manheim are also devoted to the problem of mass and mass culture. Mannheim analyzes the problem of mass culture through social, political and economic processes in society [10]. He explains the phenomenon of mass culture by not only the mass' social transformations, but the elite's also. He relates changing of the status of high culture in society with the increase of the number of elite groups, the loss of their identity, mutual neutralization. And all these phenomena happen in a society because of mass democracy.

Since the theory of industrialism was formulated, popular culture as a typical phenomenon of industrial society has become the object of attention of many researchers. The main causes of the outbreak and spread of mass culture are considered to be the following:

$\checkmark$ urbanization,

$\checkmark$ the destruction of relationships and community ties,

$\checkmark$ start of development of civil society,

$\checkmark$ the spread of education.

\section{Attributes of Mass Culture}

Specialists find the following attributes of mass culture: the dominance of consumerism over the informative-cultural values acquired for the purposes of entertainment as sale items; multiple reproduction of these items and their 
stereotyping by the latest technical facilities; focus on fashionable forms and advertised styles; stereotyped tastes, intellectual criteria. But opinions about mass culture are different. A number of specialists express the view that standardization that increases the profitability of mass culture, disseminated globally through the media, teaches consumers to the kitsch, to the dictate of fashion and the stereotypes that impede the preservation and development of the intellectual and artistic traditions of national culture and world culture as a whole. This leads to commercialization and integration of mass media with an advertising business because profits, intellectual and cultural activities, social media features are incompatible.

In the second half of the 20th century such concepts as "man-locator" (D. Riesman), "one-dimensional man" (H.Marcuse), "self-alienated personality" (E. Fromm) were born. E. Fromm believes that the cause of loneliness of modern man, his alienation from social institutions lies in economic activities, in an attempt to achieve financial independence. Because of capitalism, according to E. Fromm, a man turns into a giant economic machine, "detail", in relation to which it is totally insignificant [7]. The best way to get away from reality, in which a person feels helpless and weak, is a popular culture with its compensatory function. But in this world "the distinction between I myself and the surrounding world disappears"[7]. The central concept of $\mathrm{H}$. Marcuse is that "a resident of modern civilization is ruled by the totalitarian universe of technical rationality". Man, forced into a conformist to adjust to the outside world, has a consumer ideology" [12].

D. Riesman binds the change of human characteristics with the shift from internal to external events that come from the surrounding world. A modern man lives like radar, being ruled as a person-Locator [17].

D. Bell, unlike their predecessors, systematizes the meaning of mass: the mass as undifferentiated multitude (as opposed to class), characterized by conformism, irresponsibility, loss of individuality; mass as a synonym to ignorance, dullness; mass as a mechanized society [3].

\section{Mass Culture of the Information Society}

\subsection{Mass Culture and Mass Media}

According to D. Bell, mass is the majority of the population, and popular culture is available to them. But popular culture of 1990-2000s is definitely different from mass culture of 1950-1980s. Many scientists write that mass media determine the development of modern mass culture. According to a well-known Canadian researcher in the field of mass media, $\mathrm{M}$. McLuhan, the decisive factor of the particular socioeconomic system is a generative change of ways of communication [11]. Type of society is largely determined by the type of communication, human perception and speed of broadcasting of information. In particular, in the history of civilization McLuhan identifies three main stages:

1) prewriting primitive culture with oral forms of communication and information based on the principles of a collective way of life;

2) writing-print culture ("the Gutenberg Galaxy"), replacing collectivism by individualism;

3) modern stage where communication takes place on an electronic basis, using the television broadcasting network.

By means of mass media a modern man finds himself in a situation of "plurality of worlds and cultures". McLuhan distinguishes television, which is characterized by the following characteristic features: building television picture mosaic representing the whole world as a set of unconnected messages among themselves; resonance of these messages in the minds of the audience, combining them into a coherent semantic unity.

TV communication is a mosaic with a variety of spots and stains. The viewer actively participates in the development of mosaic television, adds his own image, depending on the level of his education, life experiences, attitudes and moods during watching TV shows. With the help of mass media people are capable to estimate and identify themselves.

A. Toffler continues to study the culture of the information society in conjunction with mass media. Modern culture is an image production, clip-culture, as A. Toffler denotes it [19]. The main feature of the new reality is a great deal of information, modern man often does not have time to handle it properly. In such conditions, according to American futurologist, we follow a natural transition to a new type of information-adapted person. In the new society a culture adapts itself by individual consumer needs. The level of culture is different in comparison to the civilization of the second wave (industrial): popular culture continues to exist to meet the needs and desires of the population's majority, but the elite culture is beginning to play the role of cultural reference. This phenomenon Toffler denotes as demassification of culture.

M. Castells believes that the terms "mass" and "popular culture" exist in the informational society, but in a modified 
version [9]. Cultural industry, according to M. Castells, is focused, firstly, on the economy of common sense. Secondly, new economic format is standardized, which means the unification of the cultural product. Thirdly, mass culture still has the function of psychological protection as a man always needs some "holiday". The phenomenon of mass culture continues to exist in the informational society in the form of the entertainment industry, as well as in areas associated with a standardized way of thinking. Another researcher of the phenomenon of mass culture in modern society is a FrancoItalian philosopher U. Eco. He believes that the main problem connected with changing of the way of information is not the extreme of its visualization, but subjects' capacity to critical perception [5]. U. Eco believes that in the nearest future the society will be composed of representatives of visual culture and elite. Representatives of visual culture will not be able to check information and prefer to get ready patterns. The elite will be able to select and use information.

According to Eco, the modern culture creates a virtual space that is simultaneously real and illusory. This is a unity of signs duplicating world. This process of copying, however, is a necessary element of perception of the subject, because the world outside of the signs does not exist. Any symbolic world for Eco, whether photos or movies, is a coded reality allowing the subject to design the world around himself. . Toffler states that critically thinking citizen of the thirdwave civilization, has the ability not to analyze but the ability to synthesize.

The famous French philosopher and sociologist A. Mol acknowledges, like many other researchers, that "the nature of contemporary culture is mosaic, collected from individual pieces" [13]. "You have to get used to the idea that we are surrounded by a mosaic culture, this culture determines our actions." Mole thinks "mosaic culture" is the cumulative product of abundance of all kinds of knowledge and the technical means of mass communication. He writes that it would be wrong to attribute to culture only works of art, culture - semantic or aesthetic facts of everyday life.

We should, of course, accept Mol's conception that culture is the set of all sorts of phenomena, when one occurs on the place of another, previous one disappears, like a computer text. Thus, we deal with picture puzzle. At the same time, as each puzzle, a modern popular culture is not a genuine reality. It's a fictional, artificial reality.

J. Baudriard presents popular culture as a culture of hiperreality [2]. He calls the unit of non-genuine sense of culture a "simulacrum". Baudriard's main idea is that we're trying to understand as the manifestation of reality only the image of reality. "Simulacrum" denies reality, hides it. At the same time, the reality is the only thing that does not exist. At the first stage of its existence simulacrum reflects deep reality, on the second stage it disguises reality, on the third stage it disguises the absence of deep reality, on the fourth stage it fully breaks with reality and becomes in fact a simulacrum. After the formation of the simulacrum the exchange between characters and reality ends: characters interact only with each other and form a hyperreality consisting of the characters. Baudriard sees a wide variety of events and phenomena as simulacrums and finds their virtuality, because they are filled with meaning only because of their perpetual repeatability. Modern mass media, according to Baudriard, replace reality, substitute it.

Another problem of creativity of J. Baudriard is corporeality. He believes that the rampant sexuality in modern popular culture is a sign of disease, is the common binge. But the modern popular culture imitates, simulates the eroticism. It's possible to change this quality of culture only by practice of bans of various kinds.

The Russian researcher V.Podoroga also appeals to the modern mass culture [16]. He differentiates three strata of mass culture: culture of labour (this includes everything that is determined by saving human efforts in time-space); culture of memory (this culture can be described as "high"); culture of leisure time (the main strata, from the author's point of view, presents entertainment, popular culture).

Podoroga notes that modern popular culture or culture of entertainment gradually subjugates high culture. "High culture" is destroyed, ceases to exist as an independent phenomenon, it is marginalized. High culture products are forced to adjust to the wishes of the masses. To survive high culture tries to serve the taste of crowds. What we call mass culture is not a culture, it's an environment in which some cultures live, other cultures are transformed and others begin to evolve rapidly. And world culture will become the global media in the nearest future.

\section{Perspectives of the Development of Culture}

\subsection{Resume}

We shall try to draw some conclusions what are the perspectives of the development of culture and humanity in general.

The main content of human activity, of course, has always been a culture as the product of creativity. Meanwhile the disproportion between cultural values, traditions of spiritual life and technological level are clear now. Obviously, a special type of public formations is made.

Technosphere is the mechanism required for the integration of humanity within a single communication network. But at the same time tehnosubstance requires a huge amount of energy in the biosphere to sustain its operation. And as 
a result we see a substantial transformation of biosphere: natural landscape is transformed, thousands of species are destroyed or found on the verge of extinction, the atmosphere is changed, we follow "greenhouse effect".

V. I. Vernadsky writes that the man destroys the balance between nature and person by his actions [20]. As a result - the alienation of a man from nature.

The technogenic civilization has put a man into the difficult conditions of existence. Today the moral right is the right of one person; everything is based on the private interest. Material achievement is one of the reasons for the dominance of popular culture, because the quality of its products is measured by commercial interest, i.e. high or low ratings. And so the philosophy of mass culture is a philosophy of material success.

The pursuit of success, striving for complete independence requires a lot of efforts, both physical and emotional. In this situation protective psychological functions of mass culture are easily explained.

Thanks to modern mass media, as well as a number of other technical means, popular culture creates a new virtual reality, substitutes a genuine one. And we deal with contemporary mass culture - Baudriard's simulacrum.

Mass culture is a set of individual episodes, fragments, clips. But these are features of popular culture of the informational civilization when everyone builds his own fragments of a "picture-puzzle". And high culture disappears according to many researchers. If elite culture is destroyed under the pressure of mass, the culture of the future will remain unchanged and will continue to bear the aggression and the satisfaction of personal desires and needs of the public.

It's necessary to note here about keeping of ethnic cultures in many ways. Cultural unification by means of today's mass culture is partly mitigated by the diversity of forms in which it exists. And we follow high plasticity and adaptability, flexibility, the ability to retain its essential quality with significant external transformations. We can say that today's popular culture has different variants: American, Japanese and Russian.

Russian variant is an unusual mixture of folk culture (ethnic music groups), copies of Western examples of mass culture (talk shows) and adopted for masses high culture (film adaptations). This variant can lead to the end of the whole Russian culture as real cultural phenomena and values disappear in this situation. Discussing this problem in Russia we cannot say anything about regional features. We find there some examples when people try to keep their ethnic values, but new generations don't follow their traditions, as the influence of mass media is too great. And mass media spread only Western examples of mass culture, stereotyped and standardized.

Mass culture is a planetary phenomenon, caused by the growth of high technology and information space. But still, it would be a mistake to equate a mass culture based on the intercultural integration and globalization on the basis of stereotyped patterns. That's why in the second half of the 20th century a trend of cultural differentiation disappears. Not only respect for other cultural traditions and values, but also the awareness of his own traditions and values should be a condition for the further development of intercultural communication and intercultural dialogue. And modern popular culture in its global modern form is a system of values, lifestyle, style and way of thinking of the American cultural model. Each ethno-national identity has its own mentality, values, traditions, customs, in contrast to mass culture, elusive, and based on technological progress, and on the desire to please an audience. The solution of this problem depends on the content of future generations, generations of civilization of the third wave.

\section{References}

Atfild, R. (1990). The Ethics of Environmental Responsibility. M. Education.

Baudriard, J. (2000). The Symbolic Exchange and Death. M. Rolf.

Bell, D. (1964). The End of Ideology. Glencoe.

Berdyaev, N. (1990). The Philosophy of Inequality. M.: IMA-press.

Eco, U. (2004). The History of Beauty. McMillan.

Freud, S. (2011). Uber der Traum. Munchen.

Fromm, E. (2006). A Man for Himself. Cambridge University Press.

Gvardini, R. (1990). The End of New Time. The Questions of Philosophy, 4, 134-142.

Kastels, M. (2000). The Information Age: Economy, Society and Culture. M. Science.

Manheim, K. (2005). Individual and Society in the Age of Transformation. New York.

McLuhan, M. (2007). Gutenberg's Galaxy: the Making of Printing man. London Penguin Books.

Marcuse, H. (2003). One-dimensional Man. Minsk: Harvest.

Mol, A. (2005). Social Dynamic of Culture. M.: KomBook.

Nietzsche, F. (1979). Philosophy and Truth. Atlantic Highlands. New Jersey: Humanities Press.

Ortega-and-Gasset, H. (2004). The Revolt of the Masses. Cambridge University Press.

Podopoga, V. (2005). Culture and Reality. Field"s Notes. M.: Pragmatics of Culture.

Riesmen, D. (1953). The Lonely Crowd. N.Y. 
Schopenhauer, A. (2006). The Art of Controversy. London Penguin Books.

Toffler, A. (2004). The third Wave. M.: AST.

Vernadsky, V. (1988). Philosophical Thoughts of Naturalist. M. Science. 